$14^{\text {th }}$ Conf. Agric. Develop. Res., Fac. of Agric., Ain Shams

Univ., March, 2019, Cairo, Egypt

Special Issue, 27(1), $519-527,2019$

Website: http://strategy-plan.asu.edu.eg/AUJASCI/

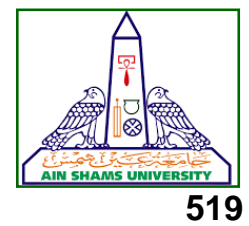

\title{
GENETIC DIVERSITY ASSESSMENT OF IN VITRO IRRADIATED TOMATO ( $L$ YCOPERSICON ESCULENTUM MILL.) USING SCOT MARKERS
}

\author{
Helmy, O. ${ }^{1}$, Abo Doma A.H. ${ }^{2}$, El-Fiki A. ${ }^{1}$, Eman M. Fahmy ${ }^{2}$, El-Metabteb G. \\ and Adly M. ${ }^{1}$
}

1. Natural Products Research Dept., National Center for Radiation Research and Technology, Atomic Energy Authority, Cairo, Egypt.

2. Genetics Dept., Fac. of Agric., Ain Shams Univ., P.O. Box 68, Hadyek Shoubra11241, Cairo, Egypt

*Corresponding author: Osama_biotech@yahoo.com

Received 9 October, 2018,

Accepted 14 October, 2018

\section{ABSTRACT}

Tomato (Lycopersicon esculentum Mill.) is considered the major and important globally vegetable crops especially in Egypt. Tissue culture techniques have facilitated the induction of mutant which helps in crop improvement. The mutation induction in vegetative crops through tissue culture may be the optimal method to improve these crops. Tomato explants of Idkawy Egyptian cultivar were cultured in vitro on MS medium supplemented with $0.2 \mathrm{mg} / \mathrm{L} \mathrm{BAP}$. The resulted plantlets were irradiated with different gamma radiation doses $(50,100,150,200$ or $250 \mathrm{~Gy})$ and the survival and mean of shoot length decreased as gamma radiation doses increased. The survival percentages of irradiated plantlets were ranged from $78.75 \%$ with 50 Gy dose to $18.75 \%$ with 250 Gy dose, while the shoot length values were decreased by a rate of $2.71 \mathrm{~cm}$ for dose $50 \mathrm{~Gy}$ and $1.2 \mathrm{~cm}$ for $250 \mathrm{~Gy}$ dose. The ten SCoT primers amplified a total of 114 amplicons with a range from 4 with SCoT-4 primer to 18 amplicons with SCOT-5 primer with an average of 11.4 amplicons per primer, The radiation specific markers were ranged from one fragment with SCoT-1 and SCoT-2 primers, SCoT5 two fragments with primer to five fragments with SCoT-3 and SCoT-33 primers.

Keywords: Tomato, Idkawy cultivar, tissue culture, radiation, SCoT markers, DNA polymorphism.

\section{INTRODUCTION}

Tomato (Lycopersicon esculentum Mill.) is the second most important vegetable crop next to potato. Present world production is about 100 million tons fresh fruit from 3.7 million hectare. In Egypt, tomatoes are cultivated on about $3 \%$ of total cultivated area and grown in the three seasons; winter, summer and autumn (FAO, 2016). Plant tissue culture techniques are recognized as useful instruments in tomato improvement. Many different applied experiments were conducted on tomatoes in vitro for their commercial value of the crop and its amenability for further improvement via genetic manipulation (Evans, 1989). Several studies have been conducted on plant regeneration from a wide range of tissues and organs of wild and cultivated tomato germplasm (Cassells 1979, Zapata et al 1981). Electromagnetic radiations are of various types such as gamma rays, X-rays, visible light, and UV rays (Wi et al 2005). Gamma rays are ionizing rays that react with atoms and molecules present inside the cells to produce free radicals. Production of free radicals depends on the irradiation level that causes damage or modification of components in plants, ultimately affecting morphology, physiology, anatomy, and biochemistry of plants (Ali et al 2016).

The SCoT markers have been successfully used to evaluate genetic diversity and structure, identify cultivars, and for quantitative trait loci (QTL) mapping and DNA fingerprinting in different species, including wheat, rice, check pea, sugar- 
cane and grape (Collard \& Mackill 2009 and Que et al 2014).

The objectives of this study were to examine the gamma irradiation impact on survival and growth of tomato plantlets (Lycopersicon esculentum Mill.) for Idkawy cultivar and the assessment of start codon targeted (SCOT) markers for analysis of the genetic diversity amang the control and irradiated plants.

\section{MATERIALS AND METHODS}

\section{Materials}

Tomato seeds of Idkawy cultivar were obtained from Vegetable Research Institute, Agricultural Research Centre, Giza, Egypt.

\section{Methods}

Seeds were sterilized by dipping in Clorox $(30 \%)$ for ten minutes followed by three rinses in sterile distilled water. The seeds were cultured on solid MS medium (Murashige and Skoog 1962) without any hormone. Micropropagation was done after 6-8 weeks when the plantlets were about 10$12 \mathrm{~cm}$ in high. The culture was maintained by cutting it into single nodes. The cultured MS medium was supplemented with different hormone types and concentrations as shown in Table (1). The $\mathrm{pH}$ of the culture media was adjusted to 5.7 before autoclaving them and the buds were thereafter incubated in agrowth chamber at $25^{\circ} \mathrm{C} \pm 2$ under photoperiod of $16 \mathrm{~h}$.

Table 1. Different concentrations of NAA, IAA BAP, KIN and IBA growth regulators which used in six MS media of Idkawy tomato cultivar for in vitro experiment

\begin{tabular}{|c|c|}
\hline $\begin{array}{l}\text { Medium } \\
\text { no. }\end{array}$ & Different growth regulators \\
\hline 1 & $\begin{array}{l}\mathrm{MS}+30 \mathrm{~g} / \mathrm{L} \text { sucrose } \\
+8 \mathrm{~g} / \mathrm{L} \text { agar } 8 \mathrm{mg} / \mathrm{L} \text { NAA+0.01mg/L KIN }\end{array}$ \\
\hline 2 & $\begin{array}{l}\mathrm{MS}+30 \mathrm{~g} / \mathrm{L} \text { sucrose } \\
+8 \mathrm{~g} / \mathrm{L} \text { agar }+0.5 \mathrm{mg} / \mathrm{L} \text { IAA }\end{array}$ \\
\hline 3 & $\begin{array}{l}\mathrm{MS}+30 \mathrm{~g} / \mathrm{L} \text { sucrose } \\
+8 \mathrm{~g} / \mathrm{L} \text { agar Without hormone }\end{array}$ \\
\hline 4 & $\begin{array}{l}\mathrm{MS}+30 \mathrm{~g} / \mathrm{L} \text { sucrose } \\
+8 \mathrm{~g} / \mathrm{L} \text { agar }+5 \mathrm{mg} / \mathrm{L} \text { BAP }\end{array}$ \\
\hline 5 & $\begin{array}{l}\mathrm{MS}+30 \mathrm{~g} / \mathrm{L} \text { sucrose } \\
+8 \mathrm{~g} / \mathrm{L} \text { agar } 0.1 \mathrm{mg} / \mathrm{L} \text { IBA }\end{array}$ \\
\hline 6 & $\begin{array}{l}\text { MS+30 g/L sucrose }+8 \mathrm{~g} / \text { Lagar+o.2mg/L } \\
\text { BAP }\end{array}$ \\
\hline
\end{tabular}

\section{Gamma irradiation treatments}

Irradiation was carried out with ${ }^{137} \mathrm{Cs}$ source at the dose rate of $1 \mathrm{~Gy} / 2 \mathrm{~min} 30 \mathrm{sec}$, at National Centre for Radiation Research and Technology, Cairo, Egypt.

Tomato seeds were soaked in water and exposed to different gamma radiation doses $(0,50$, 100, 150, 200 and $250 \mathrm{~Gy}$ ). The seeds were cultured on solid MS medium (Murashige and Skoog 1962) without any hormone. Micropropagation was applied by transferring the nodes onto MS medium supplemented with $8 \mathrm{mg} / \mathrm{L}$ NAA and $0.01 \mathrm{mg} / \mathrm{L} \mathrm{KIN}$ or $0.5 \mathrm{mg} / \mathrm{L} \mathrm{IAA}$ or $5 \mathrm{mg} / \mathrm{L}$ BAP or $0.1 \mathrm{mg} / \mathrm{L}$ IBA or $0.2 \mathrm{mg} / \mathrm{L}$ BAP.

\section{SCoT-PCR molecular markers}

Start codon targeted (SCoT) markers for assessment of genetic diversity between the control and irradiated plants were carried out according to (mansour et al 2018) .

\section{Extraction of genomic DNA}

Total genomic DNA was isolated from the control and irradiated plantlets according to the protocol described by Anderson et al (1992) with a few modifications intended to improve the quality of DNA: two consecutive extractions with phenol: chloroform $(1: 1, \mathrm{v} / \mathrm{v})$ were carried out by an additional wash of $97 \%$ alcohol (left at $-20{ }^{\circ} \mathrm{C}$ for one hour), then $70 \%$ pre-cooled ethanol, respectively. The yield and quality of DNA were assessed by gel electrophoresis.

\section{Protocol}

Ten primers of Start codon targeted (SCoT) were selected from Collard and Mackill (2009) as shown in Table (2). Amplification reactions were carried out in a total volume of $25 \mu \mathrm{l}$, which contained $250 \mathrm{nM}$ of each primer, $0.2 \mathrm{mM}$ of each deoxynucleotide, $1.5 \mathrm{mM} \mathrm{MgCl}_{2}$, 1 unit Taq polymerase, and 50- $100 \mathrm{ng}$ of template DNA. All reaction volumes were $25 \mu \mathrm{l}$ which overlaid with a drop of mineral oil. The used thermocycling program was: one cycle at $94^{\circ} \mathrm{C}$ for $3 \mathrm{~min}, 35$ cycles at $94^{\circ} \mathrm{C}$ for $50 \mathrm{sec}, 1 \mathrm{~min}$ at $50^{\circ} \mathrm{C}, 2 \mathrm{~min}$ at $72^{\circ} \mathrm{C}$, and the final extension step for $7 \mathrm{~min}$ at $72^{\circ} \mathrm{C}$. Electrophoresis was done to visualize the PCR amplified product. It was carried out on $1.0 \%$ agarose gel and amplified fragments were visualized by staining with ethidium bromide. 
Table 2. Primer names, nucleotide sequences and GC\% of the ten used SCoT primers.

\begin{tabular}{|c|c|c|c|}
\hline No. & Primer name & Sequences $\left(5^{\prime} \rightarrow 3^{\prime}\right)$ & GC $\%$ \\
\hline 1 & SCoT-1 & 5'-CAACAATGGCTACCACCA-3' & 50 \\
\hline 2 & SCoT-2 & 5'-CAACAATGGCTACCACCC-3' & 56 \\
\hline 3 & SCoT-3 & 5'-CAACAATGGCTACCACCG-3' & 56 \\
\hline 4 & SCoT-4 & 5'-CAACAATGGCTACCACCT-3' & 50 \\
\hline 5 & SCoT-5 & 5'-CAACAATGGCTACCACGA-3' & 50 \\
\hline 6 & SCoT-12 & 5'-ACGACATGGCGACCAACG-3' & 61 \\
\hline 7 & SCoT-13 & 5'-ACGACATGGCGACCATCG-3' & 61 \\
\hline 8 & SCoT-16 & 5'-ACCATGGCTACCACCGAC-3' & 56 \\
\hline 9 & SCoT-20 & 5'-ACCATGGCTACCACCGCG-3' & 67 \\
\hline 10 & SCoT-33 & 5'-CCATGGCTACCACCGCAG-3' & 67 \\
\hline
\end{tabular}

\section{Data analysis}

The size of SCoT fragments was estimated by comparison with the DNA marker. SCoT fingerprints were recorded in the binary form $(1=$ presence of a band and $0=$ absence) of the amplified products for each sample using GelAnalyzer3 (http://www.gene.ga2h.com), (Gel Analyzer Version three, 2007).

\section{RESULTS AND DISCUSSION}

\section{In vitro tomato plantlets propagation}

Tomato explants were cultured on MS medium with the combination of different growth regulators such as KIN, IAA, 6-BAP or IBA as shown in Table (3) to get the best growth rates with any of these hormones. The effect of the used hormones was measured on callus formation and the different plantlet growth rates. The MS medium supplemented with $0.2 \mathrm{mg} / \mathrm{L}$ BAP was the best one to be used for tomato explant regeneration.

\section{Effect of gamma radiation on survival of tomato plantlets}

The survivals irradiated plantlets were decreased with increasing gamma radiation doses as shown in Table (4). The survival percentages of irradiated tomato plantlets were ranged from $78.75 \%$ with 50 Gy to $18.75 \%$ with 250 Gy. As well the means of plantlets shoot length $(\mathrm{cm})$ were decreased with increasing gamma radiation doses as shown in Table (4) and Figure (1). They were 2.71 $\mathrm{cm}$ with 50 dose Gy and $1.2 \mathrm{~cm}$ with 250 Gy dose. The use of ionizing radiation, such as X-rays, gamma rays and neutrons for inducing variation, is well established. Induced mutations have been used to improve major crops such as wheat, rice, barley, cotton, peanuts, tomato and beans, which are seed propagated. Gamma ray is an ionizing radiation where they react with atoms or molecules to produce free radical in cells. Radicals may have harmful effect or act on rearranging the cell components and this effect may appear on the morphology, physiology, biochemistry and anatomy depending on radiation doses. These effects include changes in the plant cellular structure and metabolism, e.g., dilation of thylakoid membranes, alteration in photosynthesis, modulation of the antioxidative system and accumulation of phenolic compounds (Kovacs \& Keresztes 2002 and Wi et al 2005). Chronic exposure has largely been used, but does not appear to have any advantages over acute irradiation (Sigurbjörnsson, 1977). Generally, gamma irradiation can be used to obtain varieties that are economically important in agriculture, with high productivity and quality (El-Fiki 1997 and Jain 2010). They are useful for mutations in breeding programs and in vitro mutagenesis in order to develop required features of plants and increase the genetic variability. Many mutant varieties, which are resistant to biotic and abiotic stress and with high quality, have been developed (Jain et al 2013). Several attempts of mutagenic treatment on cultured anthers have been reported in higher plants (Ling et al 1991 and El-Fiki et al 2015). These results were in accordance with radiation sensitivity test done by (El-Fiki et al 2015) for tobacco, (El-Fiki 1997) for potato, (El-Fiki et al 2005) for alfalfa, (Norfadzrin et al 2007) for tomato and okra (Kiong et al 2008) for Orthosiphon stamineus. 
Table 3. The effect of the four growth regulators which added to the six MS media on the growth rates of tomato plants.

\begin{tabular}{|c|c|c|c|c|c|}
\hline $\begin{array}{l}\text { Medi- } \\
\text { um no. }\end{array}$ & \begin{tabular}{|c|} 
Different \\
growth regu- \\
lators
\end{tabular} & $\begin{array}{l}\text { Plantlets } \\
\text { For- } \\
\text { mation }\end{array}$ & $\begin{array}{l}\text { Callus } \\
\text { for- } \\
\text { mation }\end{array}$ & $\begin{array}{c}\text { Shot } \\
\text { for- } \\
\text { mation }\end{array}$ & $\begin{array}{c}\text { Root } \\
\text { for- } \\
\text { mation }\end{array}$ \\
\hline 1 & $\begin{array}{c}\text { MS+8mg/L } \\
\text { NAA+0.01mg/ } \\
\text { L KIN }\end{array}$ & + & + & + & - \\
\hline 2 & $\mathrm{MS}_{\text {IAA }} 0.5 \mathrm{mg} / \mathrm{L}$ & ++ & - & + & + \\
\hline 3 & $\begin{array}{l}\text { MS Without } \\
\text { hormone }\end{array}$ & +++ & - & + & + \\
\hline 4 & $\begin{array}{c}\mathrm{MS}+5 \mathrm{mg} / \mathrm{L} \\
\text { BAP }\end{array}$ & - & - & + & - \\
\hline 5 & $\underset{\text { IBA }}{M S+0.1 \mathrm{mg} / \mathrm{L}}$ & +++ & - & + & + \\
\hline 6 & $\begin{array}{c}\mathrm{MS}+0.2 \mathrm{mg} / \mathrm{L} \\
\text { BAP }\end{array}$ & ++++ & - & + & + \\
\hline
\end{tabular}

Table 4. The effect of gamma radiation doses on number of growing plantlets, bud survival percentage and mean of shoot length from 80 tomato/ plantlets.

\begin{tabular}{|c|c|c|c|}
\hline \multirow{2}{*}{$\begin{array}{l}\text { Radiation } \\
\text { GY/dose }\end{array}$} & \multicolumn{2}{|c|}{ Plant number survival } & \multirow{2}{*}{$\begin{array}{c}\text { Mean of } \\
\text { shoot } \\
\text { length }\end{array}$} \\
\hline & $\begin{array}{c}\text { No. of } \\
\text { growing } \\
\text { plantlets }\end{array}$ & $\begin{array}{c}\text { Bud } \\
\text { survival } \\
\text { percentage }\end{array}$ & \\
\hline Control & 74 & 92.5 & 5.30 \\
\hline 50 & 63 & 78.75 & 2.71 \\
\hline 100 & 59 & 73.75 & 2.30 \\
\hline 150 & 40 & 50.00 & 2.00 \\
\hline 200 & 32 & 40.00 & 1.54 \\
\hline 250 & 15 & 18.75 & 1.20 \\
\hline
\end{tabular}

\section{SCoT-PCR molecular markers}

The polymorphism of irradiated tomato using PCR products

Total genomic DNA from the control and irradiated tomato (Idkawy cultivar) with different gamma radiation doses 50, 100, 150, and 200 Gy were used as templates for SCoT genetic diversity analysis (250 Gy treatment was discarded for its bad results). The ten SCoT primers which selected according to Collard and Mackill (2009) as shown in Table (2) were used. These SCoT primers amplified a total of114 amplicons with a range from 4 with SCoT-4 to 18 with SCoT-5 amplicons per primer with an average of 11.4 amplicons per primer as shown in Table (5). The amplification products were varied from primer to another.

\section{SCoT specific markers}

The tested SCOT primers with radiation treatments exhibited that five of these primers were successful to generate specific markers as; SCoT1, SCoT-2, SCoT-3, SCoT-5 and SCoT-33. The radiatied specific markers were ranged from one fragment with SCoT-1 and SCoT-2 primers, two fragments with SCoT- 5 to five fragments with SCoT-3 and SCoT-33 as shown in Table (6). Recently, start codon-targeted (SCoT) markers were successfully used to assess and analyze the plant genetic diversity (Fang-Yong et al 2014 and Jiang et al 2014 and Zhang et al 2015).

Table 5. SCOT fragment patterns generated for irradiated tomato with differente gamma radiation doses.

\begin{tabular}{|c|c|c|c|c|c|}
\hline No. & $\begin{array}{c}\text { Primer } \\
\text { name }\end{array}$ & $\begin{array}{c}\text { MS } \\
\text { (bp) }\end{array}$ & $\begin{array}{c}\text { Total no. of } \\
\text { fragments }\end{array}$ & $\begin{array}{c}\text { No. of polymor- } \\
\text { phic fragments }\end{array}$ & $\begin{array}{c}\text { polymorphism } \\
\%\end{array}$ \\
\hline $\mathbf{1}$ & SCoT-1 & $137-686$ & 13 & 9 & 69.2 \\
$\mathbf{2}$ & ScoT-2 & $277-1166$ & 10 & 6 & 60.0 \\
$\mathbf{3}$ & SCoT-3 & $258-1302$ & 14 & 7 & 50.0 \\
$\mathbf{4}$ & SCoT-4 & $283-484$ & 4 & 2 & 50.0 \\
$\mathbf{5}$ & ScoT-5 & $161-1426$ & 18 & 12 & 66.6 \\
$\mathbf{6}$ & ScoT-12 & $172-747$ & 15 & 13 & 86.6 \\
$\mathbf{7}$ & SCoT-13 & $159-1174$ & 12 & 9 & 75.0 \\
$\mathbf{8}$ & SCoT-16 & $133-684$ & 5 & 1 & 20.0 \\
$\mathbf{9}$ & ScoT-20 & $285-953$ & 8 & 3 & 37.5 \\
$\mathbf{1 0}$ & SCoT-33 & $255-1463$ & 15 & 7 & 46.6 \\
\hline Total & & & 114 & 69 & \\
\hline Aver- & & & $\mathbf{1 1 . 4}$ & $\mathbf{6 . 9}$ & $\mathbf{5 6 . 1 5}$ \\
age & & & & & \\
\hline
\end{tabular}

$\mathrm{MS}=$ Molecular size $\mathrm{bp}=$ Base paire 
SCoT markers have been proved to be useful in genetic diversity studies because of their high reproducibility and great power for the detection of polymorphism (Cao et al 2006, Sofalian et al 2009, Guo et al 2012 and Hamidi et al 2014). The SCOT technique is based on the single primer amplified region principle since it uses a single primer as a forward and reverse primer, like the RAPD or ISSR technique. However, PCR amplification using SCOT primers targets gene regions surrounding the ATG initiation codon on both DNA strands. Generally, SCOT markers were reproducible but the factors determining reproducibility as primer length and annealing temperature are not the sole factors (Collard and Mackill, 2009). The PCR amplification profile of SCoT markers indicated adominant marker like RAPD and ISSR markers. The SCOT markers are expected to be linked to the functional genes and corresponding traits, thus the amplicons can be converted to gene targeted marker systems (Xiong et al 2011). Besides these markers are multilocus, which are helpful in obtaining high genetic polymorphism. The number of amplicons of the SCOT markers observed in the present study is comparable to the results obtained in other studies such as in groundnut (Xiong et al 2011), mango (Luo et al 2010), and Dendrobium nobile (Bhattacharyya et al 2013).

Table 6. SCoT primer names and the specific markers generated for radiation treatments.

\begin{tabular}{|c|c|c|}
\hline \multirow{2}{*}{$\begin{array}{c}\text { Primer } \\
\text { name }\end{array}$} & \multicolumn{2}{|c|}{ Specific markers for radiation } \\
\hline & $\begin{array}{l}\text { Negative } \\
\text { markers }\end{array}$ & Positive markers \\
\hline SCoT-1 & $219 b p$ & 0 \\
\hline SCoT-2 & $277 \mathrm{bp}$ & 0 \\
\hline SCoT-3 & $\begin{array}{l}1276,1026 \\
559,476 \mathrm{bp}\end{array}$ & 483bp \\
\hline SCoT-5 & $259,231 b p$ & 0 \\
\hline SCoT-33 & 0 & $1179,1439,704,547,420 \mathrm{bp}$ \\
\hline
\end{tabular}

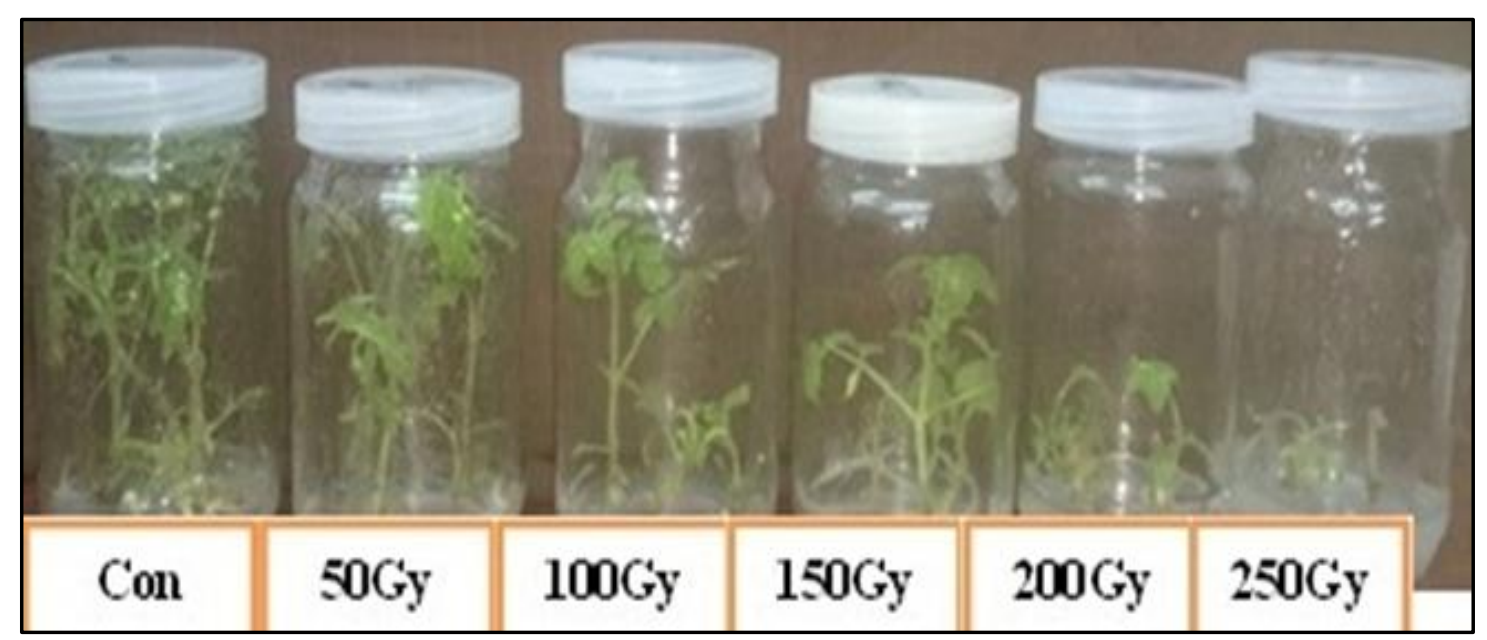

Fig. 1. Effect of gamma radiation on of survival tomato plantlets. 


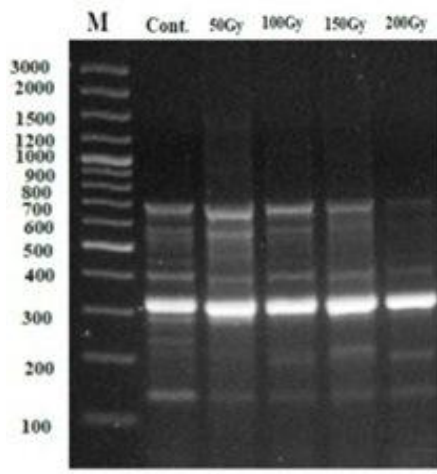

A

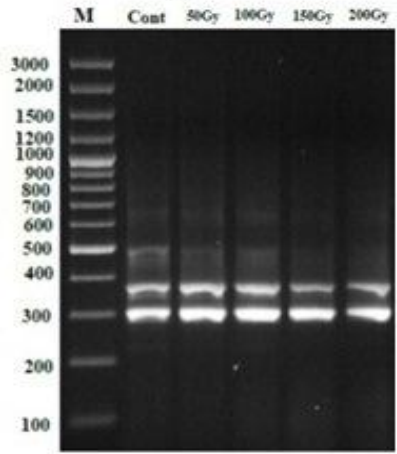

D

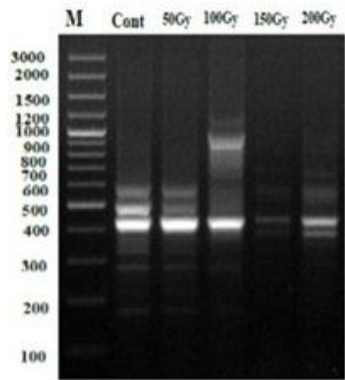

G

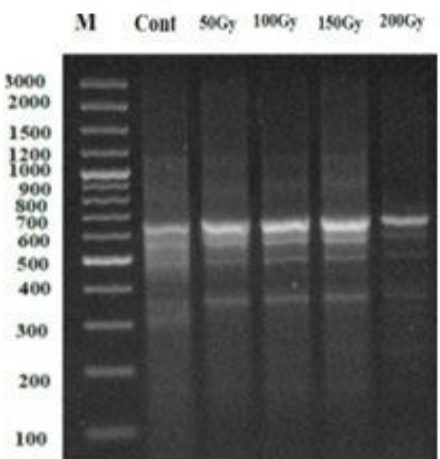

B

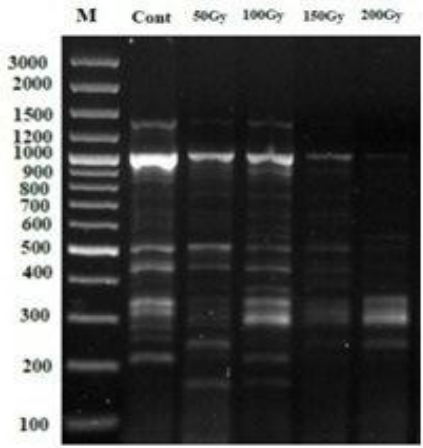

E

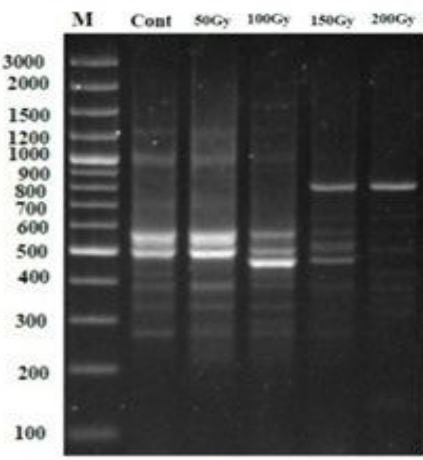

C

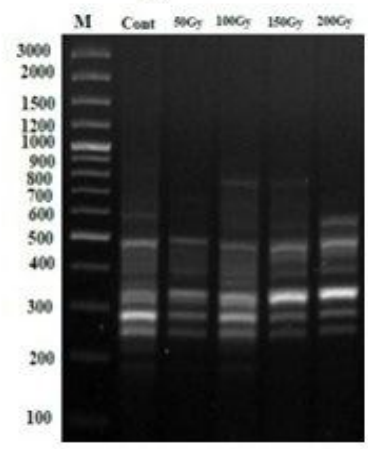

F

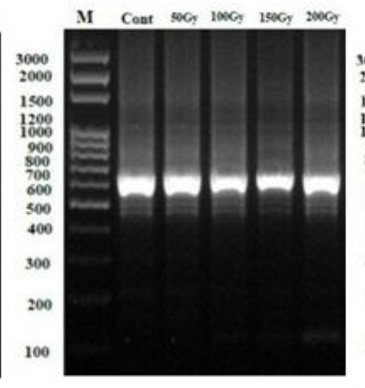

$\mathrm{H}$

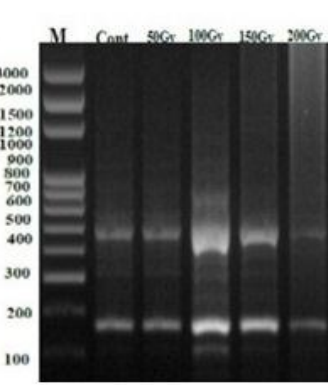

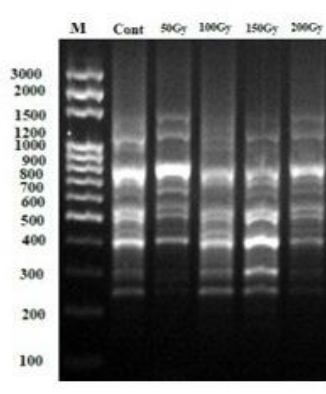

J

Fig. 2. Representative of SCOT profile for irradiated tomato plants with gamma radiation doses $(0$, $50,100,150$ and $200 \mathrm{~Gy}$ ) with (A) SCoT 1, (B) SCoT2, (C) SCoT3, (D) SCoT4, (E) SCoT5, (F) SCoT12, (G) SCoT13, (H) SCoT16, (I) SCoT20 and (J) SCoT33 primers

\section{REFERENCES}

Ali.H., Ghori Z., Sheikh S. and Gul A. 2016. Effects of gamma radiation on crop production. Crop Production and Global Environmental. Issues. pp. 27-78.

Anderson J.A., Huprikar S.S., Kochian L.V., Lucas W.J. and Gaber R.F. 1992. Functional expression of a probable Arabidopsis thaliana potassium channel in Saccharomyces cerevisiae. Proc. Natl. Acad. Sci. USA. 89, 37363740.
Bhattacharyya P., Kumaria S., Kumar S. and Tandon P. 2013. Start Codon Targeted (SCoT) marker reveals genetic diversity of Dendrobium nobile Lindl. an endangered medicinal orchid species.

Cao P.J., Yao Q.F., Ding B.Y., Zeng H.Y., Zhong Y.X., Fua C.X.and Jin XF. 2006 . Genetic diversity of Sinojackia dolichocarpa (Styracaceae), a species endangered and endemic to China, detected by inter-simple sequence repeat (ISSR). Biochem Syst. Ecol. 34, 231239. 
Cassells A. 1979. The effect of 2, 3, 5triiodobenzoic acid on calogenesis in callus cultures of tomato and pelargonium. Physiol. Plant 37, 239-246.

Collard B.C.Y. and Mackill D.J. 2009. Start Codon Targeted (SCOT) polymorphism: A simple novel DNA marker technique for generating gene-targeted markers in plants. Plant Molecular Biology 27, 86-93.

Dewi I.S., Purwoko B.S., Aswidinnoor H. and Somantri I.H .2004. Kultur antera padi pada beberapa formulasi media yang mengandung poliamin. Journal Bioteknologi Pertanian 9 (1), 14-19.

Dwivedi K., Srivastava P, Verma H.N.and Chaturvedi H.C. 1990.Direct regeneration of shoots from leaf segments of tomato (Lycopersicon esculentum Mill.) cultured in vitro and production of plants, Indian J. Exp. Biol., 28, 32-35.

El-Fiki A., El-Metabteb G., Sayed A.and Adly M .2015. Androgenesis induced in Nicotiana alata and the effect of gamma irradiation. Notulae Scientia Biologicae 7(1), 66-71.

El-Fiki A., Sayed A.and Abdel-Hameed A.A.M. 2005. Genotype, explant, medium, light and radiation effects on the in vitro plant regeneration in alfalfa (Medicago sativa L.). Isotope and Radiation Research 37(2), 437-453.

El-Fiki A. 1997. Induction of genetic variability by using gamma radiation and selection for salt tolerance in vitro in potato (Solanum tuberosum). J. Genet Breed. 51, 309-312.

Evans D. A. 1989. Somaclonal variation - Genetic basis and breeding applications, Trends in Genetics 5, 46-50.

Fang-Yonga Ch. and Ji-Honga, L. 2014. Germplasm genetic diversity of Myrica rubra in Zhejiang Province studied using inter-primer binding site and start codon-targeted polymorphism markers. Scientia Horticulturae, 170, 169-175.

FAO. 2016. The FAO Statistical Databases and Data-sets (FAOSTAT) Production Statistics. http://www.fao.org/faostat/en/\#data/QC.

Gresshoff P.M. and Doy C.H. 1972. Development and differentiation of haploid Lycopersicon esculentum (tomato). Planta, Berlin, 107, 161-170.

Guo D., Zhang J.Y. and Liu C.H.2012. Genetic diversity in some grape varieties revealed by SCoT Analyses. Mol Biol Rep. 39, 53075313.
Hamidi H., Talebi R. and Keshavarzi F. 2014. Comparative efficiency of functional genebased markers, start codon targeted polymorphism (SCoT) and conserved DNA-derived polymorphism (CDDP) with ISSR markers for diagnostic fingerprinting in wheat (Triticum aestivum L.). Cereal Res Commun., 42(4), 558567.

Jain S.M., Brar D.S., Ahloowalia B.S 2013. Somaclonal variation and induced mutations in crop improvement. Springer Science \& Business Media., pp. 15-37.

Jain S.M. 2010. Mutagenesis in crops improvement under the climate change. Romanian Biotechnological Letters 15, 88-106.

Jawahar M, Mohamed S.V. and JayabaIanN.1997, In vitro callus culture and plant regeneration from different explants of Lycopersicon esculentum Mill. J. Phytol. Res., 10, 7578.

Jiang, H., Ren X., Yan Z., Chen Y., Zhou X., Huang L., Lei Y., Huang J., Yan L., Qi Y., Wei W. and Liao B.2014. Genetic diversity and population structure of the major peanut (Arachis hypogaea L.) cultivars grown in China by SSR markers. Journal PLoS ONE 9(2), 1-10.

Kiong ALP., Lai A.G., Hussein S. and Harun A. 2008. Physiological responses of Orthosiphon stamineus plantlets to gamma irradiation. American- Eurasian Journal of Sustainable Agriculture 2(2),135-149.

Kovács E. and Keresztes, Á. 2002. Effect of gamma and UV-B/C radiation on plant cell, Micron 33, 199-210.

Ling D.X., Luckett D.J. and Darvey N.L .1991. Low-dose gamma irradiation promotes wheat anther culture response, Aust $\mathbf{J}$ Bot 39, 467474.

Luo C., He X.H., Chen H., Ou S.J. and Gao M.P. 2010. Analysis of diversity and relationships among mango cultivars using Start Codon Targeted (SCoT) markers. Biochem. Syst. Ecol. 38, 1176-1184.

Mansour H. M. H.M., Hamideldin N.,AbdelTawab F.M. and Fahmy E.M. 2018. Markerassisted Selection of New Compounds in Moringa oleifera Lam. Induced by Gamma Irradiation. Egypt. J. Rad. Sci. Applic., 31, 49 62.

Miceska G. 2011. Determination of the level of androgenesis in tobacco (Nicotiana tabacum L.). Journal of Central European Agriculture, 12(3), 515-518. 
Murashige T. and Skoog F. 1962.A revised medium for rapid growth and bioassays with tobacco tissue culture. Physiol. Plant. 15, 473-497.

Norfadzrin F., Ahmed O.H., Shaharudin S.and Abdul Rahman. D.2007. A Preliminary Study on Gamma Radiosensitivity of Tomato (Lycopersicon esculentum) and Okra (Abelmoschus esculentus). International Journal of Agricultural Research, 2(7), 620-625.

Que Y.X., Pan Y.B., Lu Y.H., Yang Y., Yang C., Huang N. and Liping Xu. 2014. Genetic analysis of diversity within a Chinese local sugarcane germplasm based on start codon targeted polymorphism. Bio Med Res Int.; pp. 1-10

Sigurbjornsson B. 1977. Induction of mutation in wheat, Academy of Sciences, Ukranian SSR, Kiev, USSR,41, 204-217.

Sofalian O., Chaparzadeh N. and Dolati M. 2009. Genetic diversity in spring wheat landraces from northwest of Iran assessed by ISSR markers. Not Bot. Horti Agrobot Cluj-Napoca 2, 252-256.
Wi S.G., Chung B.Y., Kim., J.H., Baek, M.H., Yang D.H., Lee J.W. and Kim J.S. 2005. UItrastructural changes of cell organelles in Arabidopsis stem after gamma irradiation. J. Plant Biol., 48(2), 195-200.

Xiong F., Zhong R., Han Z., Jing J., He L., Zhuang W. and Tang R., 2011. Start codon targeted polymorphism for evaluation of functional genetic variation and relationships in cultivated peanut (Arachis hypogaea L.) genotypes. Mol. Biol. Rep. 38, 3487-3494.

Zapata F.J., Sink K.C. and Cocking E.C. 1981. Callus formation from leaf mesophyll protoplasts of three Lycopersicon species: L. esculentum, cv. Walter, L. pimpinillifolium and L. hirsutum F. glabratum. Plant Sci. Lett., 23, 4146.

Zhang J., Xie W., Wang Y. and Zhao X. 2015. Potential of start codon targeted (SCoT) markers to estimate genetic diversity and relationships among chinese Elymussibiricusaccessions. Molecule. 20, 5987-6001. 

المؤتمر الرابع عشر لبحوث التنمية الزراعية،

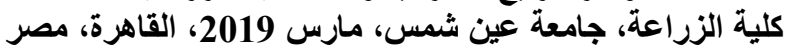

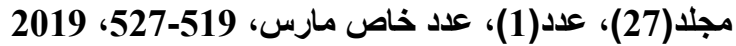

Website: http://strategy-plan.asu.edu.eg/AUJASCl/

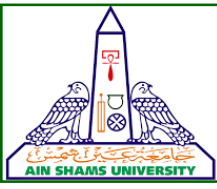

التنوع الوراثي فى نباتات الطماطم المشععه بإستخدام كثافات إستهداف شفرة البداية

Start Codon Targeted (SCoT)

[48]

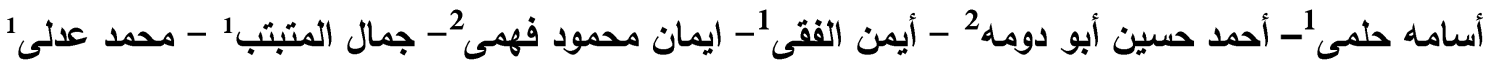

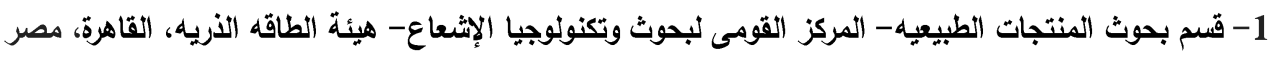

2- قسم الثوراثة- كلية الزراعة- جامعة عين شمس - ص.ب 68 - حدائق شبرا 11241 - القاهرة- دصر

"Corresponding author: Osama_biotech@yahoo.com

Received 9 October, 2018, $\quad$ Accepted 14 October, 2018

جراى و 1.2 سم للجرعة 250 جراى. تم الحصول

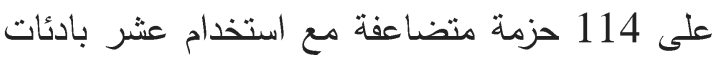

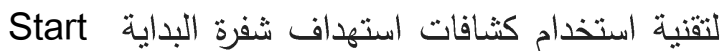
Codon Targeted (SCoT)

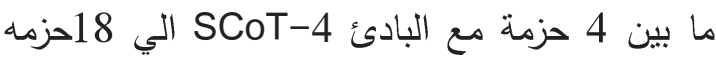
مع البادئ SCoT-5. كما أمكن الحصول على 14

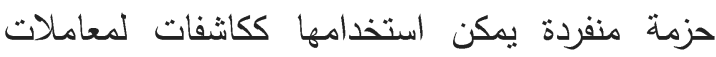
الإثعاع ، تتقسم الى 6 كاشفات موجبة ( ظهرت مع التعات

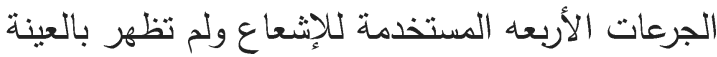
غير المعاملة كنترون) و 8 كاشفات سالبة ( إختفت

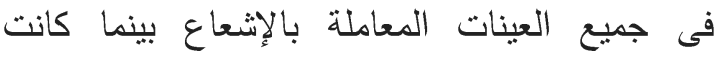
موجوده فى العينة غير المعاملة).

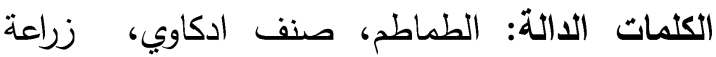

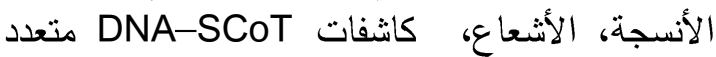

الاشكال<smiles>[Mg][TeH]</smiles>

تعتبر الطماطح من أهم المحاصيل النباتية العالمية الهامة في مصر • ساهمت تقنيات زراعة الأنسجة في الهية العالية

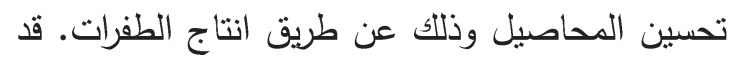
يكون انتاج الطفرات في المحاصيل الخضرية من خلاص

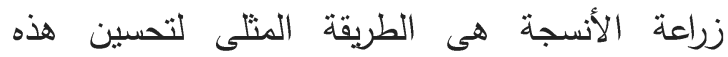
المحاصيل. تم زراعة الصنف المصري(أدكاوى) معطليا

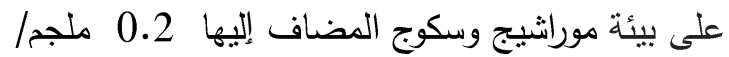
لترمن البنزيل أدينين ـ أحدثت الجرعات (50 ، 100،

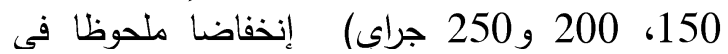

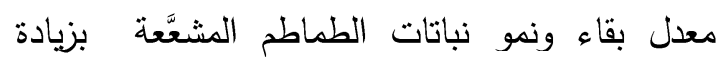
جرعة أثنعة جاما. تراوحت نسبة البقاء والحيويه للنباتات المشععة من 75.78\% بالنسبه للجرعه 50 براء جراى و 18.75٪ للجرعه 250 جراى، في حين لاتئ لات انخفض طول الساق بمعدل 2.71 سم للجرعة 50

تحكيم: ا.د أيمن حنفى عبدالعظيم

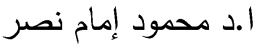

